\title{
Digi-Bags on the Go: Childminders' Expectations and Experiences of a Tablet-Based Mobile Learning Environment in Family Day Care
}

\author{
Kaisa Pihlainen (D), ${ }^{1}$ Calkin Suero Montero, ${ }^{2}$ and Eija Kärnä ${ }^{1}$ \\ ${ }^{1}$ Department of Special Education, University of Eastern Finland, Joensuu, Finland \\ ${ }^{2}$ Department of Computer Science, University of Eastern Finland, Joensuu, Finland \\ Correspondence should be addressed to Kaisa Pihlainen; kaisa.pihlainen@uef.fi
}

Received 18 August 2017; Revised 14 February 2018; Accepted 4 March 2018; Published 1 April 2018

Academic Editor: María D. Lozano

Copyright (c) 2018 Kaisa Pihlainen et al. This is an open access article distributed under the Creative Commons Attribution License, which permits unrestricted use, distribution, and reproduction in any medium, provided the original work is properly cited.

\begin{abstract}
The use of mobile technologies is playing an increasingly important role in early childhood education (ECE) settings. However, although technologies are often integrated in ECE provided in day care centres, technology use in other ECE settings, such as in family day care, is rare. In this paper, we describe the Digi-bag, a tablet-based mobile learning environment deployed at several family day care homes, and present the expectations and first experiences of family day care personnel regarding the pedagogical use of Digi-bags together with 1- to 5-year-old children as well as their experiences of training to use the digital technology. The results of the pilot study indicate that the deployment of Digi-bags facilitates the pedagogical, creative, and regular use of digital technology with small children. The study also underlines the importance of providing opportunities to family day care personnel for peer support and peer learning in natural settings besides professional training in the use of digital technologies.
\end{abstract}

\section{Introduction}

Family child care, or family day care, has been defined as care given to a small group of children in the home of a child or a family day care practitioner [1]. In the USA, this is a common form of nonparental care for young children, with more than 1 in 5 children under five years of age receiving family child care [2]. In Finland, early childhood education (ECE) is provided in day care centres and family day care homes according to Finnish legislation [3] (when emphasizing care as a part of early childhood education, the abbreviation ECEC (early childhood education and care) is used in ECE literature. In this article, we use the abbreviation of ECE to emphasize the educational aspects of professionals working with young children). In total, $68 \%$ of 1 - to 6-year-olds participate in ECE in Finland, of which $76 \%$ are in day care centres and $11 \%$ in family day care [4]. Although there are differences between day care centres and family day care [5], for example, family day care takes place at homes and the group size is limited to four children, and the same curriculum is used in both ECE settings.
Despite heavy debate, technology, in particular computer, use in early childhood has been shown to foster a number of positive traits in young children including selfconfidence, increased spoken communication and cooperation skills as well as manual dexterity, nonverbal skills, and problem solving, among others [6]. Therefore, in recent years, technology has been used increasingly to support the development of children in ECE in Finland and elsewhere. Consequently, many day care centres are currently equipped with digital technologies for use in activities with children [7]. However, this is not often the case in many family day care homes in Finland [8]. Although the use of information technology devices and software is a requirement in the competence-based qualification of family day care personnel [9], day care homes seem to lack adequate technologies for pedagogical purposes, and furthermore, support and guidance is needed to keep the technical skills of day care personnel up to date [10]. This situation may place many young children and early childhood educators in an unequal position. 
Furthermore, in Finland the requirements for family day care qualification include planning the ECE environment in a way that enables natural interactions for the children in terms of, for example, play, movement, exploration, artistic experiences, and expression, while at the same time providing a stimulating and safe and supportive environment for upbringing, care and learning [1]. It is also required to assess and adapt the learning environment regularly based on the children's needs and interests [1]. However, since good quality education and children's upbringing are ultimately based on the values of the personnel and their expectations for the future (e.g., [5]), it is crucial to study the current situation of family day care personnel regarding technology use, motivation, and experiences. Ways in which the current emphasis on technology use in ECE in Finland [11] could be integrated into the work of family day care personnel also needs to be studied.

To further our knowledge and understanding related to the abovementioned issues of technology use in family day care, three goals were set for this pilot study. Firstly, to determine the childminders' technology expectations and use prior to the Digi-bag trials. Secondly, to investigate the initial experiences of family day care personnel in using digital technologies during the digital backpack (Digi-bag, Section 2) trials with 1 - to 5-year-old children in pedagogical settings. While employing the Digi-bags in their work, the family day care personnel had the possibility to use digital technologies such as tablets and Bee-Bot robots (https://www.bee-bot.us). We examine the changes in expectations and experiences of the participating family day care personnel during deployment of these digital technologies. The experiences of educational personnel are crucial to the realization of successful learning environments since being aware of and evaluating one's own beliefs and perceptions is regarded as a core component of educational know-how that supports the provision of high-quality ECE for small children [5]. Thirdly, since the Digi-bag trials were the first project to employ digital technologies in Finnish family day care [8], we were interested in collecting and analysing the training experiences of family day care personnel in the use of digital technologies in pedagogical settings. The findings will be used to modify the training of new childminders to use Digi-bags.

Our contribution puts forward both scientific and practical measures to develop ECE best practices to respond to the current technological changes in societies. Furthermore, our work advances this discussion by introducing the Digi-bag technology-enhanced mobile learning environment in family day care and describing the childminders' expectations and initial experiences of this learning environment. In doing so, we shed light on the technical requirements and pedagogical aspects of using mobile learning technologies in ECE as well as the need for provision of further education and training for ECE personnel.

\section{Digi-Bags in Family Day Care}

The Digi-bag concept was created out of the need to provide children and childminders (i.e., the family day care personnel that participated in the Digi-bag trials) in family day care with access to digital technologies comparable to those used in day care centres. We chose backpacks because they are easily adapted to the everyday lives of small (1- to 5-year-old) children (backpacks are used daily by Finnish school and preschool children, although 0- to 1-year-olds do not carry them on their backs), and through them, we can combine familiar and new digital and nondigital tools to create handson, flexible, approachable, and playful learning experiences. As such, the Digi-bags aim at fulfilling the role of granting children equal opportunities for learning through digital technologies regardless of the ECE setting.

Each Digi-bag consists of a bag equipped with a tablet (Lenovo TAB 3, Android 6.0, 32 GT) with a protective cover, Internet connectivity, and headphones, as well as instructions and tips for using the tablet. Furthermore, each childminder had a personal memory card to be used for saving data, including photos and videos. Tablets were chosen as the main mobile technology device for family day care since with them all of the advantages of a modern-day computer can be obtained, and they are light, portable, and easy to use [12] even for very small children (e.g., two-year-olds) [13]. Furthermore, the characteristics of interaction between childminder and child in a family day care environment also support the use of tablets. That is, the distance between the adult and children is markedly smaller in family day care compared to day care centres [14]. Furthermore, compared to day care centres, children move more in family day care [14], which emphasises the advantages of mobile technology in the family day care settings.

For the trials, five Digi-bags were prepared, and the contents were customized based on one of five core content areas of the Finnish National Core Curriculum for Pre-primary Education [1]. The core content areas are (see also Table 1) as follows:

(1) Self-expression: learning self-expression through music, arts, handicrafts, and oral and physical expression,

(2) Language: learning language skills,

(3) Me and my community: learning to understand the variety of people's backgrounds, history, ethics, and religion in society and communities and to participate in the community,

(4) I explore and act: learning mathematics, technologies, and environmental education,

(5) I grow and develop: learning to look after oneself, managing daily activities from the viewpoints of physical exercise, nutrition, consumer skills, health, and safety.

We chose to equip each backpack for each core content area with tools to strengthen the practical implementation of the new curriculum [1] as well as to support the pedagogical grounding for the use of mobile technologies. Table 1 gives a brief description of each core pedagogical area, the practical methods of teaching and learning, and the tools and materials provided with the Digi-bag to support the pedagogical approach.

Each Digi-bag differed in terms of the kind of software installed on the tablet and nondigital devices, and the toys 
TABle 1: Core content areas of the Finnish National Core Curriculum for Pre-primary Education; tools and materials in the Digi-bags; practical examples of pedagogical ways to use them.

\begin{tabular}{|c|c|c|}
\hline Core area of the Finnish curriculum & Pedagogical function of the Digi-bag & $\begin{array}{c}\text { Tools and materials (digital \& nondigital) in } \\
\text { the Digi-bag }\end{array}$ \\
\hline $\begin{array}{l}\text { (1) Self-expression: emphasis on music, arts, } \\
\text { handicrafts, and oral and physical expression }\end{array}$ & $\begin{array}{l}\text { Use of imagination and creativity, } \\
\text { experimenting and expressing own ideas }\end{array}$ & $\begin{array}{l}\text { Tablet and software; chicken shakes; drum; } \\
\text { finger puppets; story book; playdough }\end{array}$ \\
\hline $\begin{array}{l}\text { (2) Language: emphasis on developing } \\
\text { language skills }\end{array}$ & $\begin{array}{l}\text { Naming and classifying objects, practicing } \\
\text { social, interactional, and cultural skills, self- } \\
\text { expression, and a combination of these skills }\end{array}$ & $\begin{array}{l}\text { Tablet and software; card game: emotions; } \\
\text { nursery rhymes; games supporting } \\
\text { storytelling and singing }\end{array}$ \\
\hline $\begin{array}{l}\text { (3) Me and my community: emphasis on } \\
\text { history, society, ethics, religion }\end{array}$ & $\begin{array}{l}\text { Getting to know dif } \\
\text { and cultures in the } \\
\text { playin }\end{array}$ & $\begin{array}{l}\text { Tablet and software } \\
\text { card game; book or } \\
\text { chi }\end{array}$ \\
\hline $\begin{array}{l}\text { (4) I explore and act: emphasis on } \\
\text { mathematics, ICT, and environmental } \\
\text { education }\end{array}$ & $\begin{array}{l}\text { Reading pictures, numbers, media, and text; } \\
\text { naming objects, learning concepts, using and } \\
\text { producing various contents, using digital } \\
\text { documentation, exploring the world }\end{array}$ & $\begin{array}{l}\text { Tablet and software; Bee-Bot robot; } \\
\text { magnifying glass; foam shapes }\end{array}$ \\
\hline $\begin{array}{l}\text { (5) I grow and develop: emphasis on physical } \\
\text { exercise, nutrition, consumer skills, health, } \\
\text { safety }\end{array}$ & $\begin{array}{l}\text { Practicing dressing, eating alone, taking care } \\
\text { of personal hygiene and own property, } \\
\text { moving safely inside and outside, } \\
\text { recognizing emotions, planning, } \\
\text { implementing, and evaluating activities } \\
\text { together, learning common rules and trust }\end{array}$ & $\begin{array}{l}\text { Tablet and software; mini bean bags; gross } \\
\text { motor exercise cards; book: theory and tips } \\
\text { on children's physical exercise in ECE }\end{array}$ \\
\hline
\end{tabular}

and games chosen to support the core content areas of the curriculum (Figure 1). For example, a Digi-bag for supporting children's language skills (core area 2) included materials for storytelling, playing with concepts, and listening to nursery rhymes, while a Digi-bag for multiliteracy and ICT competence development (core area 4) included a magnifying glass and a Bee-Bot robot (Table 1). The Digi-bags were compiled in backpack form to enable easy mobility between childminders. The participating childminders were also encouraged to write down their experiences of using the Digi-bags as well as their ideas and tips to share with other users in order to foster the circulation and adoption of new of pedagogical ideas. We believe that circulation of materials and ideas among the childminders fosters motivation and curiosity in both the children and childminders.

The Digi-bags combined tablets with zero- or lowtechnology tools and materials based on four pedagogical aspects. Firstly, use of a tablet alongside more traditional and familiar tools used in ECE supports the notion that mobile learning technologies are a natural part of the everyday life of children [15], as is the case with zero- or low-technology devices and materials. Secondly, providing a variety of tools together allows the children and personnel to freely choose and express their preferences for tools for learning, which is widely connected with motivation (e.g., [6]). Thirdly, providing a tablet with other tools and materials may trigger the imagination of the children and personnel to combine various tools for playing and learning (see [16] for more details about hybrid play). Finally, we avoided overemphasis on technology over pedagogy and activity content by providing a mixture of digital technology and nondigital traditional tools. Our goal was to strengthen pedagogically oriented use of technologies by combining them with pedagogical and content knowledge (see [17]). In practice, use of the Digi-bags depends on each childminder and the group of children and the degree of adult-driven and child-driven activity.
For the Digi-bag pilot study, childminders received five Digi-bags and a two-hour training session on use of the tablets in April 2017. As the Digi-bags were ready to use, the participating personnel introduced the bags to the children in their care immediately. The first experiences from this pilot group are presented in this study and will be used to modify the training and the contents of the following ten Digi-bags to be prepared in Autumn 2017 based on the five core areas of the new curriculum (see [11]). The bags will then be deployed for a 14-week period with all the remaining family care personnel in the municipality in which the trials were conducted.

\section{Methodology}

This pilot study of the Digi-bag trials was conducted as a case study [18]. A case study is an inquiry into a specific phenomenon (the case) within its real-world context [19]. In this study, the goal was to understand five childminders' expectations and initial experiences of the Digi-bags as part of their daily work with small children, and their experiences of the training in digital technology use. In addition, the results of the pilot case study were expected to provide information on how mobile technology-enhanced learning environment such as the Digi-bag could enrich the education of small children in family care and how childminder training in the use of technology in their daily work could be provided.

3.1. Participants. The local supervisor of the childminders introduced the Digi-bag concept and a description of the pilot study to all childminders in the municipality, and we used voluntary sampling to recruit five female childminders to participate in the trials. The number of participants was limited to five to allow one Digi-bag per childminder. The age of the childminders varied from 49 to 59 years $(M=56$ years, $\mathrm{SD}=4.2$ ). Their educational background reflected the variety 


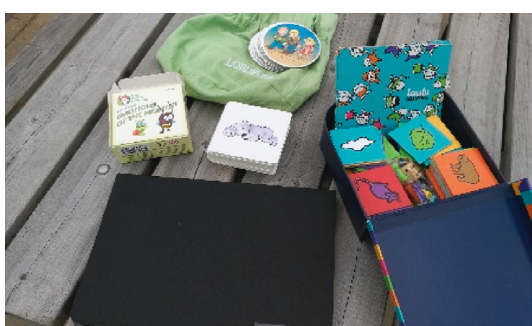

(a)

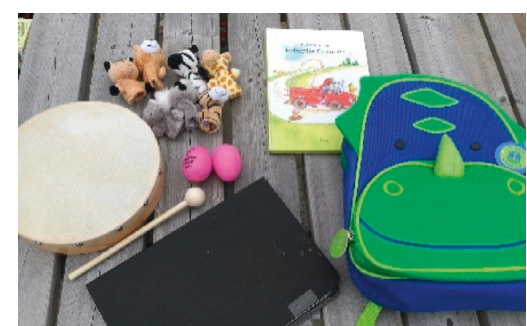

(b)

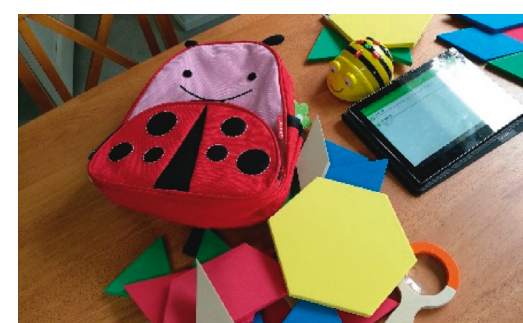

(c)

Figure 1: Examples of the Digi-bags and their contents. (a) Languages (bag not shown); (b) Self-expression (playdough not shown); (c) I explore and act.

of backgrounds of the childminders, which is also observed at the national level: two childminders had official family day care qualification, one was a day care assistant and one had a comprehensive school education. One childminder did not mention her educational background. It is notable that one of the qualified family day care childminders also had a degree in information technology and two childminders were currently undergoing further education in ECE.

All of the participating childminders were highly experienced, having worked in the field from 15 to more than 30 years $(M=23$ years, $\mathrm{SD}=6.7)$. The composition of the child groups reflected the typical, nation-wide situation in family day care. That is, each childminder took care of four children, both boys and girls. The children's age varied from one to five years. None of the children received special support.

3.2. Data Collection and Analysis. The data collection was conducted using short questionnaires with both closed and open-ended questions and unstructured interviews. Prior to the data collection, the researchers met all participating childminders as well as their local supervisor in order to negotiate the practicalities of the pilot and the best ways for data collection. For example, the childminders requested flexible data collection methods, and thus, questionnaires were provided in both online and paper formats.

The data were collected in three phases. Firstly, the childminders filled in a questionnaire to record their thoughts and expectations regarding the Digi-bag trials prior to the pilot launch. These data were collected in April 2017. Two childminders used an online form and three preferred to fill in a paper version of the questionnaire. The questionnaire included questions on the childminder's background; their use of digital technologies in educational contexts and leisure time; their expectations regarding the use of digital technology with children in ECE; their feelings regarding the use of digital technology in childminding; their thoughts on how other people (children, parents, other childminders, etc.) might perceive the use of digital technology in childminding; and their expectations of the Digi-bag pilot.

Secondly, the participating childminders reported their initial experiences of the Digi-bag use after the trials. The data were collected in July-August 2017. Three childminders responded using the online questionnaire. Thirdly, the written data were supplemented with unstructured interviews. One of the researchers visited three childminders in August 2017 to discuss their initial experiences of the Digi-bags. These qualitative data were analysed using classical content analysis $[20,21]$. The closed questions were analysed using descriptive statistical methods such as frequencies and percentage. The study practices were based on generally accepted ethical principles for scientific research. As the research was carried out in natural settings, the rights and protection of the research participants were the first priority. Participation was voluntary, and all participating childminders and the guardians of the children in care gave their written consent prior to the trials.

\section{Results}

4.1. Technology Expectations and Use Prior to the Trials. The childminders had some experience of using digital technologies prior to the Digi-bag trials, mostly from pastime activities. However, digital technologies were less used for pedagogical activities with children in family day care (Table 2). Nevertheless, three childminders described using digital technologies sometimes (varying from weekly to less than monthly use) in different pedagogical ways, such as finding craftwork instructions or searching for information about animals. They also used digital devices for reading fairy tales, taking photos, and listening to music. Two childminders, however, had no prior experience of using digital technologies in a pedagogical context with children.

When asked about the different ways they could use digital technology with children in ECE, the childminders mostly mentioned uses that are already familiar to them, such as searching for information online, taking photos, listening to music, and watching videos. The childminders' responses also included examples of taking photographs not only to capture images and memories but also to collect children's feedback or as means to react to children's current interests. For example, a child could take photos from his or her day or of their favourite objects.

In addition, the childminders mentioned age-appropriate digital games that could support the children's development and learning (Figure 2). For example, one childminder wrote that "now the children are interested in letters (so there is a need for), a game with which we could listen to and write letters and words."

Overall, all of the childminders positively anticipated the use of digital technologies. They described the children's excitement to use digital devices not only at home but also in family day care. From their personal viewpoint, the 
TABle 2: Childminders' digital technology use prior to the Digi-bag trials (F).

\begin{tabular}{|c|c|c|c|c|c|c|c|c|}
\hline \multirow[t]{2}{*}{ Childminder } & \multicolumn{4}{|c|}{$\begin{array}{l}\text { How often do you use the following digital technologies } \\
\text { in your free time? (F) }\end{array}$} & \multicolumn{4}{|c|}{$\begin{array}{l}\text { How often do you use the following digital technologies } \\
\text { with children in family day care? (F) }\end{array}$} \\
\hline & Mobile phone & Computer & Tablet & Other $^{1}$ & Mobile phone & Computer & Tablet & Other \\
\hline$\# 1$ & 5 & 4 & 1 & 1 & 3 & 3 & 2 & 1 \\
\hline$\# 2$ & 5 & 5 & - & - & 2 & 2 & - & - \\
\hline$\# 3$ & 5 & 4 & 5 & 3 & 4 & 2 & 4 & - \\
\hline$\# 4$ & 5 & 2 & 2 & - & 1 & 1 & 1 & 1 \\
\hline$\# 5$ & 5 & 5 & - & - & 1 & 1 & 1 & 1 \\
\hline
\end{tabular}

${ }^{1}$ Video/photo cameras and Blu-ray players.

$\mathrm{F}=$ frequency; $5=$ daily; $4=$ weekly; $3=$ couple of times a month; $2=$ less than monthly; $1=$ not at all; $-=$ data missing.

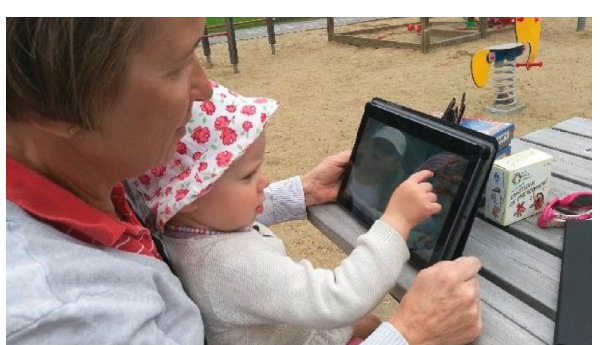

(a)

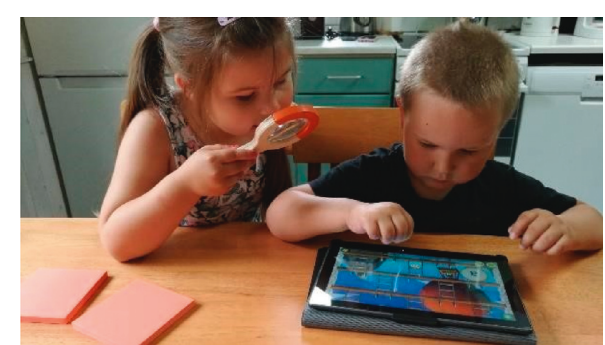

(b)

FIGURE 2: Children using a tablet in family day care.

childminders related technology use to easing and enriching their work tasks with the children and as a way of learning something new. Learning new activities seemed to be exciting for the childminders as one respondent wrote, "I have not been a huge mobile phone user before, so it will be interesting to see how the Digi-bag trial goes with us, because I will also be learning almost from scratch.” Besides positive reactions, some respondents also shared some concerns towards technology use in family day care. One childminder expressed that "the challenge is how I can offer anything new. It feels like the children are cleverer than I am." Some childminders also worried about a possible decrease in playtime but simultaneously recognized the possibility for new play and games to emerge.

4.2. First Experiences with the Digi-Bags. During the trials, the childminders used the Digi-bags once or twice a week with the children. Tablets were regarded as versatile tools in family day care and were used both indoors and outdoors. Two interviewed childminders emphasized that tablets were very beneficial for taking photos and videos, which were useful for recalling earlier activities. As one childminder noted, "I think it is great that you can take photos of trips. The kids love to watch them afterwards and wonder at what they did." Besides these familiar activities with tablets, the childminders also discovered new, creative ways to use tablets in daily life with the children. For example, one childminder described a situation before a day nap as follows: "(tablets are handy because now) I can read fairy tales from the tablet also in a dark room."

Although one childminder reported that their children were not really interested in using a tablet in family day care as it was an ordinary device at home, most of the childminders had overall positive initial experiences of using the tablets provided with the Digi-bags. They explained how the children each took turns using the tablet while the other children observed the user at a close distance. Some childminders reported that they were very surprised to see how smoothly and effortlessly turn-taking and rule-following took place among the children. Childminders also reported that they had found ways to communicate and negotiate the rules of tablet use. Children were taught, for example, to store the tablet in a safe place and not to leave it on the floor.

When the children used the tablet, the childminders observed them from a close distance and were able to provide help if needed. Although in most cases the children used the tablets in groups, the childminders emphasized the importance of noticing each child as an individual, whose unique habits and needs in using the technology had to be taken into account. In this way, the childminders could, for instance, intervene when they observed a child's excessive use of the tablet.

Furthermore, the childminders referred many times to the children's acquisition of skills while using the tablet. For example, one childminder explained that even a one-year-old child was able to play with a tablet by herself when a childminder helped her to navigate the tablet screen and "turn off different pages." Learning was connected with playful activities enabled by the different software and technologies. The childminders mentioned, for example, that the children learned letters by playing games on the tablets, practiced musical skills outdoors using QR codes that were read with the tablets, and used Bee-Bot robots to learn traffic rules. As one childminder described: "the children had fun steering the Bee-Bots with the arrow keys. They drove forward, left, right, and backward along streets on their traffic play mat. At the same time we discussed, for example, how a pedestrian should behave in traffic, what do the red, yellow, and green colours mean on traffic lights, and so on." Another childminder described how children who were 
taking photos and videos with a tablet of what they could see, hear, and do during a forest walk learned also turn-taking, listening to instructions, and following them. Moreover, the childminders were pleased to see that, in practice, the use of digital technologies did not diminish the children's free playtime. On the contrary, as one childminder mentioned, "I haven't seen other play give way (to tablet use), far from it, the kids are just playing (without tablets) as well."

The respondents also mentioned some critical issues related to the technical characteristics of the digital devices. For example, in bright daylight, it was difficult to see pictures on the tablet screen; the tablet was also too big and heavy for some children to carry. The need for a waterproof cover for the tablet and a softer bag to put the tablet in was also expressed. Apart from these few critical comments, the childminders' initial experiences of Digi-bag deployment in family day care were overall positive.

4.3. Experiences of Training in Digital Technology Use. The childminders expressed their eagerness to learn new perspectives regarding their work in family day care. As one childminder puts it, "it is not only the kids that are learning, also the childminders are getting tips. I really like that there is always something new, especially things that relate to my work (so) things do not get stuck in a rut. I do not want to give up what is practical, but I can always take on new ideas."

The childminders also indicated their need for training in the use of digital technologies in family day care. After a twohour technical training session, some of the childminders remained unclear regarding their own role in learning to use the technologies. Being accustomed to participating in officially organized training, they did not know whether they should investigate further uses of the tablets on their own. As one respondent wrote, "sometimes we wonder what to do. (Wait for) training or experiment by ourselves?" Some childminders seemed to have had unsatisfactory prior experiences of ICT training, which may have affected their expectations of training in Digi-bag use.

Nevertheless, for those who implemented self-regulated learning, the learned new uses seemed to be rewarding. For example, one childminder who had used digital technologies prior to the training wrote that "(it was) nice to try QRs (for day care activities) when I understood how easy it is to do them." Her activities and experiments also motivated other childminders who noticed the concrete benefits and easiness of preparing $\mathrm{QR}$ codes in practice. One childminder who observed the other childminders' work with QRs described, "I also got interested in that immediately because you can do such cool things together with the kids. And it is something I want to learn." Furthermore, the childminders explained the need for simple training programmes in the introductory phase of the new devices as well as access to written easy instructions, especially about digital games' use.

\section{Discussion}

The childminders' expectations of tablet use prior to the trials equated with their actual use of tablets at work, including information searching, music listening and, photo and video shooting. Even though these ways of using tablets are pedagogically justifiable (e.g., [7]), they represent only a small proportion of their use potential. We interpret this as reflecting a need to provide training for childminders about varied pedagogical possibilities of using these devices. Furthermore, training should focus on the core areas of the curriculum to support the work of the childminders [9] as well as children's upbringing, care, and learning in the most suitable ways [1].

Some childminders reported having fears prior to the Digi-bag trials of being unable to create motivating activities for their children through digital technology. These fears disappeared during the trials and, instead, the childminders described both their desire and practical ways to use tablets as pedagogical tools to support children's individual upbringing and learning. Examples such as combining the use of Bee-Bot robots with teaching traffic rules, applying QRs in forest trips, and using a tablet for reading fairy tales at nap time in a dark room reflected the motivation of the childminders to actively employ creative ways of using tablets in family day care. Motivation was spread by both sharing own practical experiences as well as listening to the experiences of peers.

The results from the first experiences of the Digi-bag trials revealed that childminders perceived tablets as a natural part of children's current and future life. The childminders reported that the children have continued using the technologies on a weekly basis in family day care after deployment of the Digi-bags. This indicates that the tablets have increased the pedagogical use of technology in the ECE settings under study; as prior to the trials, their use varied from weekly to less than monthly. Simultaneously, the Digi-bags also increased the diversity of technology use, such as using devices outside, in dark spaces, and with small children. This diversity reflects the benefits of using tablets for pedagogical activities as have also been noted elsewhere (e.g., $[12,22])$. After the first experiments with tablets, the childminders contested their own preconceptions about the decrease in children's playtime. This is crucial, since play is regarded as a central part of supporting children's development, learning, and well-being in ECE settings [1].

The concerns that the childminders had about the children's use of digital technologies during the trials were mostly linked with the technical characteristics of the tablets, such as size, weight, and the functionality of the screen in outdoor use. Even though technical characteristics, such as lightness, portability, and ease of use, were the main reason for choosing tablets for family day care use, we noticed their limitations when the users are small children. Therefore, we hope to provide more child-friendly digital technologies, including tablets and smart phones, even for small children.

The childminders themselves also asked for more training in technology use. This request is relevant since the use of technologies in ECE was included in the latest core curriculum for pre-primary education launched in 2016 in Finland. As Friedrichs-Liesenkötter [23] states, ICT training for ECE personnel "can be regarded as part of the response to the debate around the quality and the professionalization of ECE." Based on the experiences of the childminders, both training organized by professionals and possibilities for 
peer support are needed to further educate childminders in the use of digital technologies. Peer collaboration with tablets has been recorded also elsewhere as supporting learning in further education [22]. Our study shows that peer support and working together with peers may motivate less experienced childminders to experiment with digital technologies in natural settings.

When considering the expectations and first experiences of the childminders, it should be taken into account that only five childminders participated in the Digi-bag preliminary trials. However, the findings of usability research indicate that five individuals can reveal around $80 \%$ of key issues during technology testing [24]. Moreover, five participants were specifically chosen in order to pilot five Digi-bags that were based on the five core content areas of the Finnish National Core Curriculum for Pre-Primary Education. Although the number of participants was limited in our trials, their experiences corresponded well with previous studies. However, further Digi-bag trials should be undertaken with larger participant numbers and more varied cultural and/or educational settings.

\section{Conclusion}

This paper introduced the Digi-bag mobile learning environment launched for use in family day care with small children and their childminders. The preliminary study indicated that technologies were used in family day care weekly in versatile and creative ways. In order to support childminders in employing digital mobile technologies in family day care, further training is needed. Training should reflect the current situation of the childminders as technology users with attention paid to the attitudes, fears, and frustrations of the childminders. Alongside official training, childminders should be provided opportunities for peer support and peer learning in authentic settings. To this end, the Digi-bag trials provided a fruitful starting point for implementing a mobile learning environment in family day care.

Finnish ECE is holistic in nature, emphasizing the interrelatedness of upbringing, teaching, and care [5]. Mobile learning environments seem to fit well with these goals. In order to strengthen children's equal rights to learning and use of digital technologies [25], we hope that in future the Digi-bag mobile learning environment will be deployed and studied in various day care settings. It would be interesting to study in detail how technology initialization happens: Do children take the initiative or are tablets used based on the childminder's prompting? How do these actions vary from each other? Ways of providing further education for childminders, such as peer training, also need further research.

\section{Conflicts of Interest}

The authors declare that there are no conflicts of interest regarding the publication of this paper.

\section{Acknowledgments}

Our sincere thanks to the ECE managers and childminders in the Liperi municipality for their collaboration in this study.

\section{References}

[1] National Board of Education, "Varhaiskasvatussuunnitelman perusteet 2016, (Fundaments of early childhood education)," Määräykset ja ohjeet, vol. 17, 2016, http://www.oph.fi/ download/179349c_varhaiskasvatussuunnitelman_perusteet_ 2016.pdf.

[2] E. M. Kryzer, N. Kovan, D. A. Phillips, L. A. Domagall, and M. R. Gunnar, "Toddlers' and preschoolers' experience in family day care: age differences and behavioral correlates," Early Childhood Research Quarterly, vol. 22, no. 4, pp. 451466, 2007.

[3] Finlex, Varhaiskasvatuslaki (Early Childhood Education Law), Ministry of Social Affairs and Health 36/1973, Helsinki, Finland, 2015.

[4] S. Säkkinen and T. Kuoppala, "Varhaiskasvatus 2015, (Early childhood education 2015)," Statistical report 21/2016, National Institute for Health and Welfare, Helsinki, Finland, 2016.

[5] K. Karila, T. Kosonen, and S. Järvenkallas, Varhaiskasvatuksen Kehittämisen Tiekartta Vuosille 2017-2030, (The Road Map for Developing Early Childhood Education for 2017-2030), vol. 30, Publications of Ministry of Education and Culture, Helsinki, Finland, 2017.

[6] K. McCarrick and Xiaoming, "Buried treasure: the impact of computer use on young children's social, cognitive, language development and motivation," AACE Journal, vol. 15, no. 1, pp. 73-95, 2007.

[7] N. Vernadakis, A. Avgerinos, E. Tsitskari, and E. Zachopoulou, "The use of computer-assisted instruction in preschool education: making teaching meaningful," Early Childhood Education Journal, vol. 33, no. 2, pp. 99-104, 2005.

[8] U. Puustinen, "Konstan digiloikka, (Konsta's digital leap)," Motiivi, vol. 6, pp. 14-17, 2017.

[9] Finnish National Agency for Education, Perhepäivähoitajan Ammattitutkinto 2013. Näyttötutkinnon Perusteet, (Further Vocational Qualification of Childminders 2013. Basics for Competence-Based Qualification), Decree 15/011/2013, Decrees and Instructions, vol. 24, Finnish National Agency for Education, Helsinki, Finland, 2013.

[10] P. Lindberg, "Tieto- ja viestintätekniikan mahdollisuudet perhepäivähoidossa (The possibilities of information and communications technology in family day care)," in Villistä Valvottuun, Valvotusta Ohjattuun. Perhepäivähoidon Ohjauksen Historia ja Nykytilan Haasteet (From Wild to Controlled, from Controlled to Supervised. The History of Family Day Care and Today's Challenges), S. Parrila, Ed., vol. 4, pp. 100-111, Sosiaali- ja Terveysministeriön Julkaisuja, Helsinki, Finland, 2005.

[11] National Board of Education, "Esiopetuksen opetussuunnitelman perusteet, (National core curriculum for pre-primary education 2014)," 2014, http://www.oph.fi/download/163781_ esiopetuksen_opetussuunnitelman_perusteet_2014.pdf.

[12] E. B. Miller and M. Warschauer, "Young children and e-reading: research to date and questions for the future," Learning, Media and Technology, vol. 39, no. 3, pp. 283-305, 2014.

[13] Common Sense Media, Zero to Eight: Children's Media Use in America 2013, Common Sense Media, San Francisco, CA, USA, 2013.

[14] J. Reunamo, "Mitä perhepäivähoidossa todella tapahtuu?, (What really happens in family day care?)," 2012, http://blogs. helsinki.fi/reunamo/files/2012/06/pph.pdf.

[15] A. Suoninen, "Lasten mediabarometri 2013: 0-8-vuotiaiden mediankäyttö ja sen muutokset vuodesta 2010, (Children's media 
barometer 2013: the media use of $0-8$ years and its changes from 2010)," Nuorisotutkimusverkosto/Nuorisotutkimusseura, Verkkojulkaisuja 75, 2013.

[16] H. Tyni, A. Kultima, T. Nummenmaa, K. Alha, V. Kankainen, and F. Mäyrä, "Hybrid playful experiences: playing between material and digital," TRIM Research Reports, no. 19, 2016, http://tampub.uta.fi/handle/10024/98900.

[17] P. Mishra and M. J. Koehler, "Technological pedagogical content knowledge: a framework for teacher knowledge," Teachers College Record, vol. 108, no. 6, pp. 1017-1054, 2006.

[18] R. K. Yin, Case Study Research: Design and Methods, SAGE, London, UK, 5th edition, 2013.

[19] R. K. Yin, "Validity and generalization in future case study evaluations," Evaluation, vol. 19, no. 3, pp. 321-332, 2013.

[20] M. W. Bauer, "Classical content analysis: a review," in Qualitative Researching with Text, Image and Sound, M. W. Bauer and G. Gaskell, Eds., pp. 132-152, SAGE, London, UK, 2000.

[21] K. Krippendorff, Content Analysis: An Introduction to Its Methodology, SAGE, London, UK, 2004.

[22] J. Butcher, "Can tablet computers enhance learning in further education?," Journal of Further and Higher Education, vol. 40, no. 2, pp. 207-226, 2016.

[23] H. Friedrichs-Liesenkötter, "Mediaeducational habitus of future educators in the context of education in day-care centers," Journal of Media Literacy Education, vol. 7, no. 1, pp. 18-34, 2015.

[24] J. Nielsen and T. K. Landauer, "A mathematical model of the finding of usability problems," in Proceedings of the ACM INTERCHI'93 Conference, Amsterdam, The Netherlands, April 1993.

[25] A. Third, D. Bellerose, U. Dawkins, E. Keltie, and K. Pihl, Children's Rights in the Digital Age: A Download from Children around the World, Young and Well Cooperative Research Center, Melbourne, VIC, Australia, 2nd edition, 2014, https:// www.unicef.org/publications/files/Childrens_Rights_in_the_ Digital_Age_A_Download_from_Children_Around_the_ World_FINAL.pdf. 


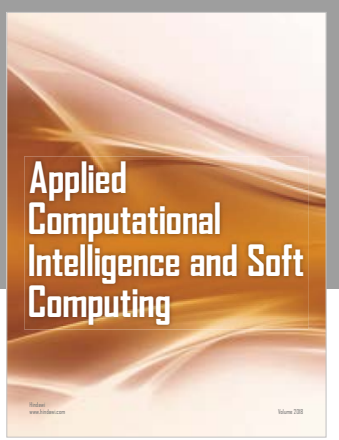

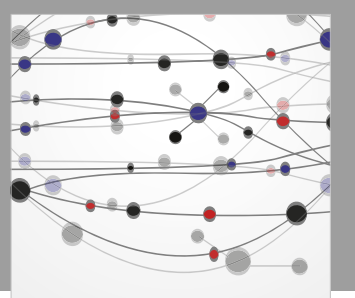

The Scientific World Journal
Submit your manuscripts at

Computing
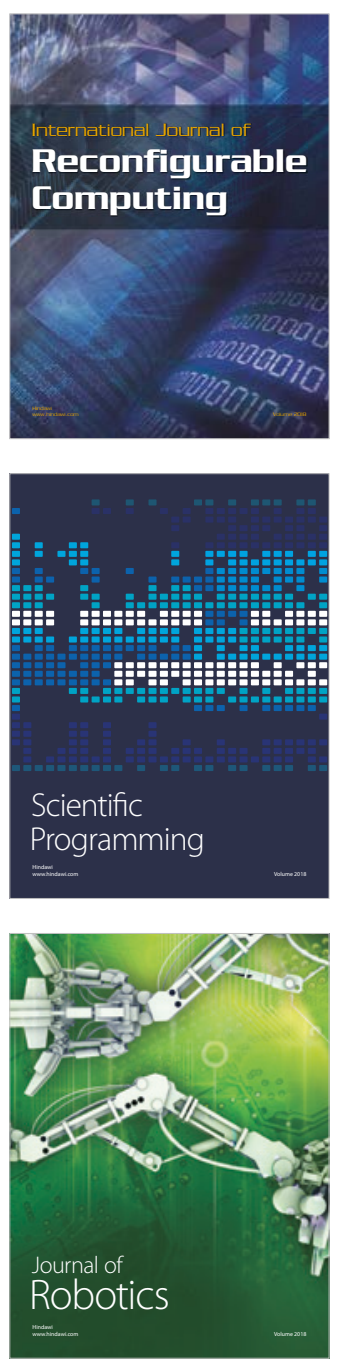

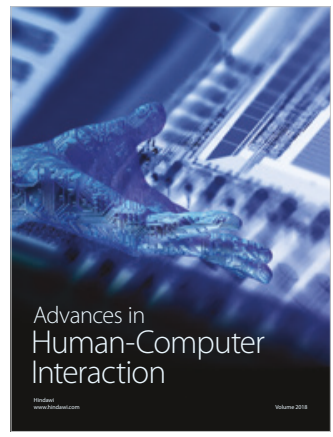

Human-Compute

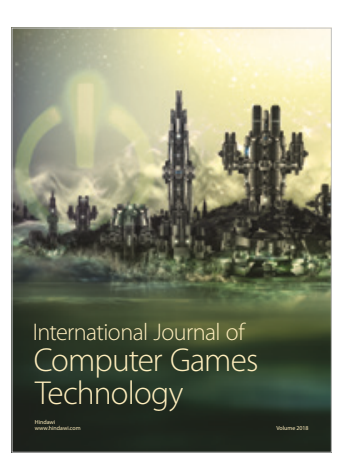

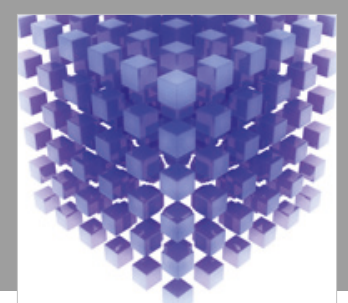

Mathematical Problems in Engineering

\section{Engincering}
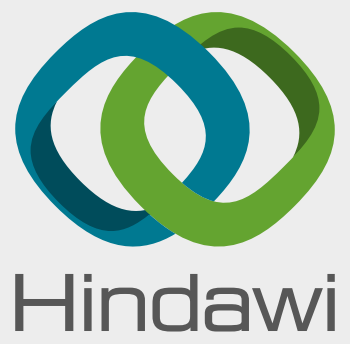

www.hindawi.com
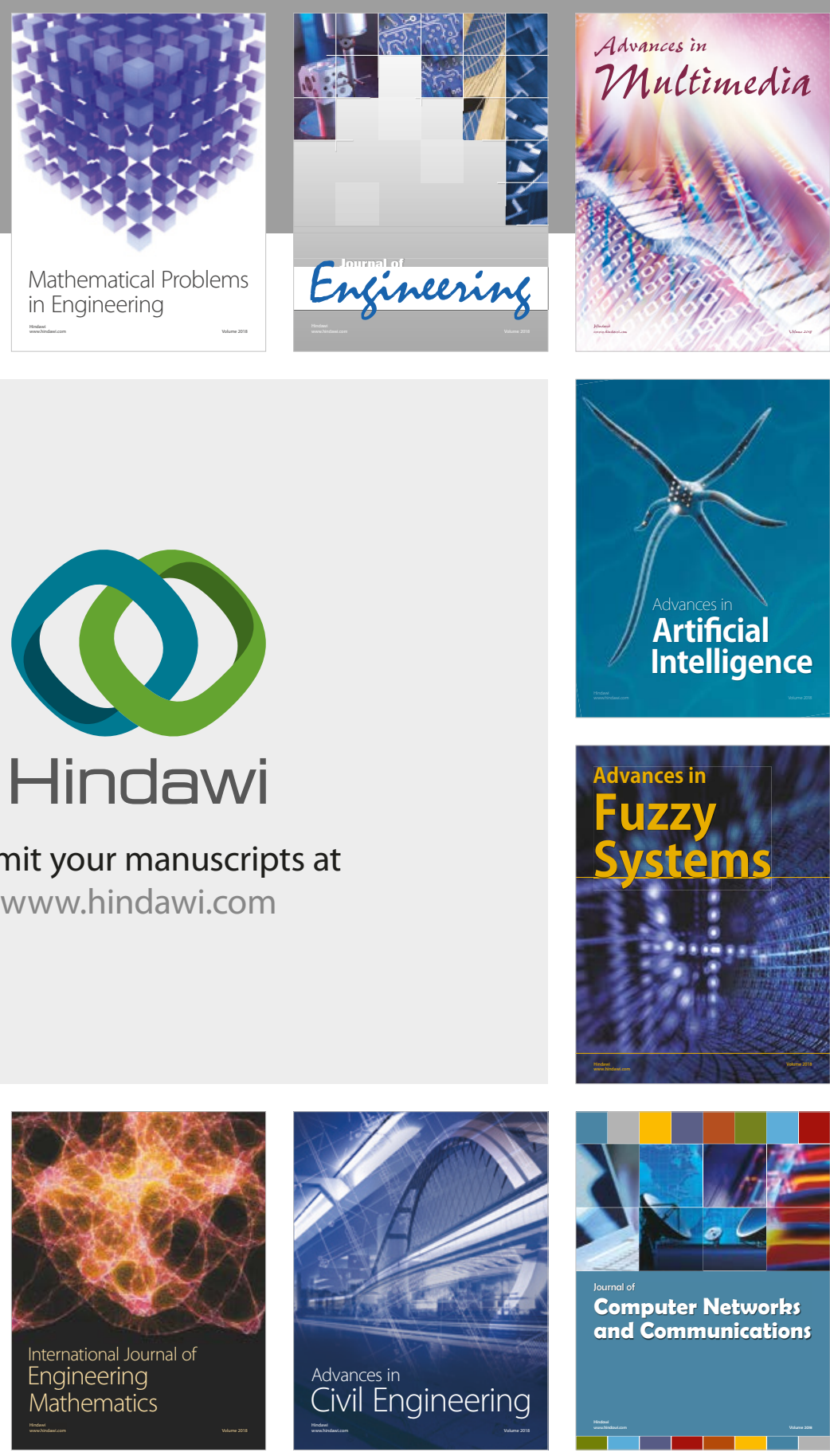

Computer Networks and Communications

Multimedia
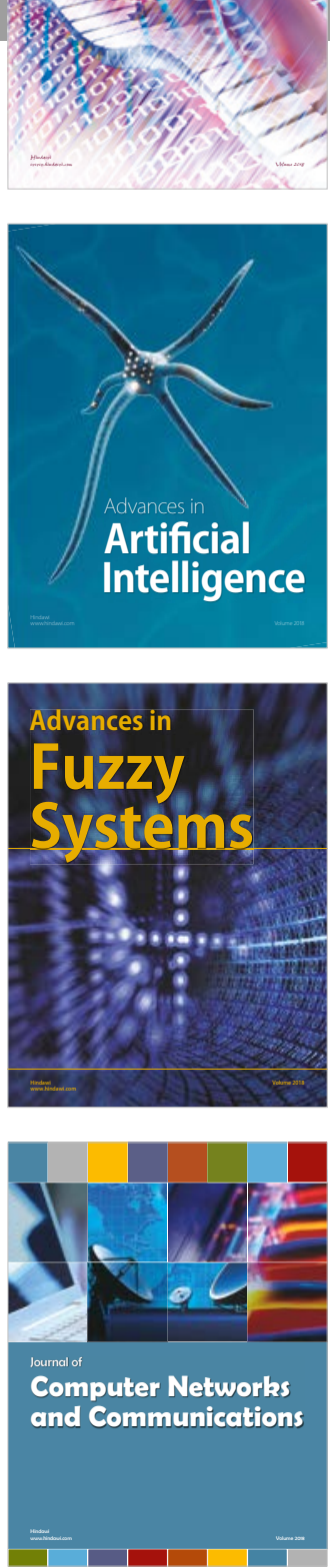

Advances in

Modelling \&

Simulation

in Engineering

interaction

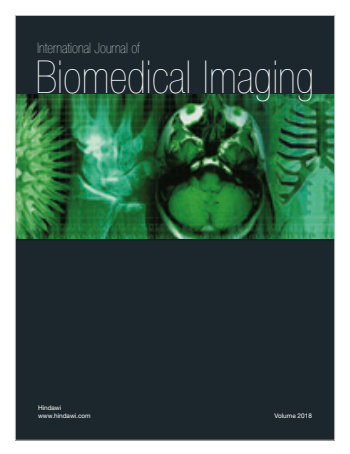

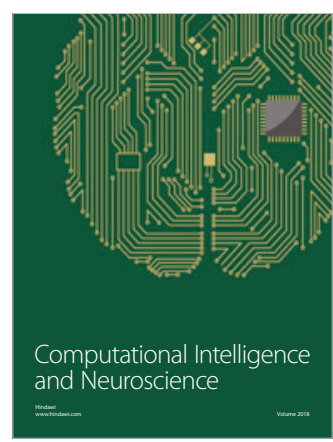

